\title{
Regulation of the Cytoplasmic Accumulation of 5-Methyltetrahydrofolate in MA104 Cells Is Independent of Folate Receptor Regulation
}

\author{
Barton A. Kamen, Catherine A. Johnson, Mei-Tai Wang, and Richard G. W. Anderson \\ Departments of Pediatrics, Pharmacology, and Cell Biology \& Anatomy, The University of Texas \\ Southwestern Medical Center, Dallas, Texas 75235
}

\begin{abstract}
To better understand how the folate receptor (also known as the membrane folate binder) is able to deliver 5-methyltetrahydrofolic acid to the cytoplasm of folate-depleted MA104 cells, we have examined the kinetics of movement from the cell surface into the cytoplasm. Bound 5-methyltetrahydrofolic acid was transferred into an acid-resistant membrane compartment at the rate of $0.9-1.0 \mathrm{pmol} / 10^{6}$ cells per $h$. This folate appeared in the cytoplasm at the same rate. Furthermore, cytoplasmic 5-methyltetrahydrofolic acid became polyglutamated at the rate of $0.6-0.7 \mathrm{pmol} / 10^{6}$ cells per $h$. As soon as intracellular 5-methyltetrahydrofolate reached 5-7 pmol $/ 10^{6}$ cells, however, cytoplasmic accumulation was markedly inhibited even though the folate receptor remained functional. Therefore, the acute regulation of 5-methyltetrahydrofolic acid accumulation appears to be achieved by controlling the movement of the vitamin from the receptor into the cytoplasm of the cell.
\end{abstract}

\section{Introduction}

Certain tissue culture cells, when grown in the presence of low concentrations ( $<5-10 \mathrm{nM})$ of 5-methyltetrahydrofolic acid, express on their cell surface a high affinity membrane receptor for folate $(1,2)$. This receptor is the membrane form $(2,3)$ of a soluble folate-binding protein found in the plasma $(4,5)$, milk (6), and placenta (7) of various animal species. Two lines of evidence suggest that this receptor mediates the delivery of physiologic concentrations of 5-methyltetrahydrofolate to the cytoplasm of folate-depleted cells: $(a)$ when KB cells are incubated in the presence of an antibody to the soluble folate binder that inhibits the binding of 5-methyltetrahydrofolic acid, the cells fail to accumulate 5-methyl $\left[{ }^{3} \mathrm{H}\right]$ tetrahydrofolic acid (1); and $(b)$ folic acid, a high affinity folate that binds to the folate receptor but is not delivered to the cytoplasm of the cell (8), blocks the cellular accumulation of 5-methyl $\left[{ }^{3} \mathrm{H}\right]-$ tetrahydrofolic acid in MA104 cells (2).

The complete amino acid sequence of the human folate receptor has been deduced from a cDNA clone (9). The sequence contains the partial human folate-binding protein sequence reported by Sadasivan and Rothenberg $(10,11)$ and

Address all correspondence to Dr. Barton A. Kamen, Department of Pediatrics, University of Texas Southwestern Medical Center, 5323 Harry Hines Boulevard, Dallas, TX 75235. 1989.

Received for publication 16 May 1989 and in revised form 7 July

J. Clin. Invest.

(c) The American Society for Clinical Investigation, Inc.

$0021-9738 / 89 / 11 / 1379 / 08 \$ 2.00$

Volume 84, November 1989, 1379-1386 the amino acid sequence of the bovine milk folate-binding protein (12). It is a glycoprotein of 257 amino acids with three potential glycosylation sites and eight potential disulfide bonds. At the amino terminus is a 20 amino acid long signal sequence. Although there is not a typical membrane-spanning region in the molecule, the $\mathrm{COOH}$ terminus ends with a stretch of 14 hydrophobic amino acids that are not present in the bovine folate-binding protein (12). The presence of a predicted $\mathrm{COOH}$-terminal hydrophobic amino acid sequence in the cDNA but an absence of the sequence in the mature protein is diagnostic for a glycosyl-phosphatidylinositol-linked protein (13). Since the receptor is released from MA104 membranes by phosphatidylinositol-specific phospholipase $C$ (9), the membrane attachment predicted by the cDNA has been confirmed by direct experimentation. Hydrolysis of this anchor could release the receptor from the membrane, thus explaining the difference between the membrane and soluble forms of this protein $(14,15)$.

We have been interested in the cellular mechanism used by the folate receptor to mediate the accumulation of 5-methyltetrahydrofolic acid by folate-depleted MA104 cells $(2,8)$. Using both 5 -methyl $\left[{ }^{3} \mathrm{H}\right]$ tetrahydrofolic acid and $\left[{ }^{3} \mathrm{H}\right]$ folic acid as ligands, four steps in the uptake process have been identified: $(a)$ binding of folate to the receptor; $(b)$ translocation of the folate-receptor complex into a compartment where it is protected from the releasing effect of low $\mathrm{pH} ;(c)$ accumulation of 5-methyltetrahydrofolate in the cytoplasm; and $(d)$ addition of multiple glutamic acid residues to form a folylpolyglutamate. Under a variety of conditions both occupied and unoccupied receptors are cyclically transferred back and forth between the acid-labile and acid-resistant compartments, and both compartments are associated with the plasma membrane fraction of the cell. We have interpreted this transfer to be movement of the receptor into a membrane-bound vacuole that is not in direct contact with the extracellular space. Approximately one-half of the receptors are in this compartment and one-half are exposed at the cell surface. The appearance of the 5 -methyl $\left[{ }^{3} \mathrm{H}\right]$ tetrahydrofolate in the cytoplasm is blocked by agents that neutralize acidic intracellular compartments; however, these agents have no effect on receptor movement, which suggests a key role for protons in the cytoplasmic delivery step (8).

If the folate receptor delivers 5-methyltetrahydrofolic acid to a vacuolar compartment, how does 5-methyltetrahydrofolate then traverse the membrane to reach the cytoplasm? Since 5-methyltetrahydrofolic acid is an organic anion, free passage across the hydrophobic lipid bilayer of the membrane seems unlikely. Transmembrane movement, however, may be facilitated by a membrane carrier mechanism. Such a carrier could be a channel-forming membrane protein that is specific for 5-methyltetrahydrofolate. Several groups of investigators have reported that transmembrane movement of folates is 
mediated by a specific carrier (16-19). Henderson and Zevely (20), as well as Price and Freisheim (21), have used a cross-linkable analogue of methotrexate to isolate putative transporter proteins that have molecular weights of 36,000 and 46,000 , respectively.

To better understand the relationship between binding of 5-methyltetrahydrofolic acid to the folate receptor and its movement into the cytoplasm of the cell, we have examined in detail the kinetics of 5-methyltetrahydrofolate movement for each step in the transfer from the cell surface into the cytoplasm. Initially, folate-depleted cells deliver 5-methyl $\left[{ }^{3} \mathrm{H}\right]$ tetrahydrofolic acid to the cytoplasm of the cell as rapidly as it appears in an acid-resistant compartment. As soon as the cells become replete with this folate, however, accumulation in the cytoplasm is markedly inhibited even though functional receptor continues to move in and out of the acid-resistant compartment. These results suggest that the receptor is coupled to a transmembrane transport step that is regulated by the cytoplasmic concentration of folate.

\section{Methods}

\section{Materials}

Tissue culture. Culture flasks (T-25) were from Costar (Cambridge, MA). Medium 199 (M199) ${ }^{1}$ with Earle's salts with (320-1150) or without (82-0002) folic acid, glutamine (320-5030), and trypsin-EDTA (610-5300) were purchased from Gibco Laboratories, (Grand Island, NY). FCS (12-10378) was obtained from Hazelton Research Products, Inc. (Lenexa, KS). Dulbecco's PBS (DPBS) was made from a standard recipe.

Chemicals and radiochemicals. Radiolabeled folic acid $\left(\left[{ }^{3} \mathrm{H}\right]\right.$; 20-40 Ci/mmol, MT783) was purchased from Moravek Biochemicals (City of Industry, CA). 5-Methyltetrahydrofolic acid and 5methyl $\left[{ }^{3} \mathrm{H}\right]$ tetrahydrofolic acid were synthesized from folic acid or $\left[{ }^{3} \mathrm{H}\right]$ folic acid using enzymatic reduction and chemical methylation as previously described (2). Folic acid polyglutamates were purchased from Dr. G. Nair, Department of Biochemistry, University of South Alabama, Mobile, AL. DL-5-Methyltetrahydrofolic acid (M-0132) and sodium Hepes (H-3375) were from Sigma Chemical Co. (St. Louis, MO). Protease inhibitors leupeptin (L-2884) and aprotinin (A-1153) were also obtained from Sigma Chemical Co.

HPLC reagents. PIC-A (tetrabutylammonium phosphate, 85191) and acetonitrile (84935) were purchased from Waters Associates (Milford, MA). HPLC-grade methanol (A-452) was from Fisher Scientific Co., Pittsburgh, PA. Deionized water was made by filtration through a model 1000 reagent water system (Hydro Service \& Supplies, Inc., Research Triangle Park, NC). All HPLC solvents were filtered through either a $0.45-\mu \mathrm{m}$ filter (HAWPO4700; Millipore Continental Water Systems, Bedford, MA) or, if the volume was $<1 \mathrm{ml}$, through a $0.45-\mu \mathrm{m}$ Millex-HV4 filter unit (SJHVOO4NS; Nihon Millipore, Yonezawa, Japan).

\section{Cell culture}

MA104 cells, a monkey kidney epithelial cell line, were grown continuously as a monolayer in folate-free M199 supplemented with $5 \%$ (vol/vol) FCS (medium A). This medium contained $\sim 10 \mathrm{nM}$ folate and $0.68 \mathrm{mM}$ glutamine. Fresh medium $A$ was added to stock cultures every $3 \mathrm{~d}$. Cells for each experiment were set up according to a standard format. On day $02.0 \times 10^{5}$ cells were seeded into a T-25 flask and grown for $4 \mathrm{~d}$ in the same medium. When the medium was assayed for folate (2), by day 4 medium A contained $<1 \mathrm{nM}$ folate and the cells

1. Abbreviations used in this paper: DPBS, Dulbecco's PBS; M199, medium 199. contained $<1 \mathrm{pmol} / 10^{6}$ cells of folate. This modification of previous culture conditions (8) avoided the use of charcoal treatment of the serum and used the normal growth characteristics of the cells to deplete the medium of folate. As a result, the cells became folate depleted by the time of the experiment. The activity of the folate receptor in these cells was indistinguishable from cells grown in folate-free medium (8). For uptake studies medium A was replaced with medium B (folate-free M199 containing $20 \mathrm{mM}$ Hepes, $\mathrm{pH} 7.2$, and $0.68 \mathrm{mM}$ glutamine) and additions were made directly to the culture flask.

\section{Measurement of folate binding and accumulation}

To measure folate receptor activity, on day 4 (see figure legends) of cell growth the medium was removed by aspiration and $1.5 \mathrm{ml}$ of medium $B$ was added to each T-25 flask. The indicated type of radiolabeled folate was added to the dish in the presence or absence of 100 -fold excess unlabeled folate and the cells were incubated for the indicated time. In some experiments the medium was replaced with fresh medium B and the cells were incubated for various times. Except for the experiments shown in Figs. 8 and 9 and Table I, at the end of the incubation the cells were chilled on ice and the medium was removed by aspiration. After rinsing with $5 \mathrm{ml}$ ice-cold DPBS, folate was released from the cells by washing rapidly for $30 \mathrm{~s}$ with $2 \mathrm{ml}$ ice-cold acid saline $(0.15 \mathrm{M} \mathrm{NaCl}$, adjusted to $\mathrm{pH} 3$ with glacial acetic acid) followed by a rinse with $1 \mathrm{ml}$ cold DPBS. The radiolabeled folate in the acid saline plus the $1 \mathrm{ml}$ cold DPBS wash represented acid-labile folate. The cells were released from the culture dish by incubating with $1 \mathrm{ml}$ trypsin-EDTA for $5 \mathrm{~min}$ at $37^{\circ} \mathrm{C}$ degrees and then rinsed twice with 1 $\mathrm{ml}$ DPBS. The trypsin-EDTA suspension and washes were combined and the amount of tritium, which corresponds to the acid-resistant folate, was determined. The acid-labile measurements shown in Figs. 8 and 9 and Table I were carried out by doing the acid wash for $30 \mathrm{~s}$ at $37^{\circ} \mathrm{C}$. Radioactivity was measured by liquid scintillation counting using a Tri-Carb counter (Packard Instrument Co. Inc., Downers Grove, IL) that had an efficiency of $\sim 40 \%$ in scintillation fluid prepared as described previously (2). All values represent specific binding or accumulation, which was calculated by subtracting the value for $\left[{ }^{3} \mathrm{H}\right]$ folate in the presence of unlabeled folate (nonspecific) from the value in the absence of unlabeled folate (total). Each value shown represents the average of duplicate incubations. Nonspecific uptake or binding was never $>5-10 \%$ of specific. Where indicated, the cell number in the trypsin EDTA suspension was determined with a hemocytometer, or the protein content was determined by the method of Bradford (22). The protein content of cells used in some of the calculations was $400 \mu \mathrm{g} / 10^{6}$ cells.

\section{Measurement of membrane and cytoplasmic folate}

Previously we separated membranes from cytoplasm using Percoll gradients (8). To simplify the methodology we lysed cells by freezethawing in a hypotonic buffer and separated the membranes from the cytoplasm by ultracentrifugation. After the labeling experiments as indicated, the cells were washed with DPBS and $1.5 \mathrm{ml}$ of buffer $\mathrm{A}(10$ $\mathrm{mM}$ Tris-base, $\mathrm{pH} 8.0,0.02 \mathrm{mg} / \mathrm{ml}$ aprotinin, $0.02 \mathrm{mg} / \mathrm{ml}$ leupeptin, and 1-10 $\mu \mathrm{M}$ DL-5-methyltetrahydrofolic acid) was added to each $\mathrm{T}-25$ flask at $4^{\circ} \mathrm{C}$ and the flasks were placed at $-80^{\circ} \mathrm{C}$ for at least 15 min. After the freezing step the cells were placed on an ice tray and 0.5 $\mathrm{ml}$ of ice-cold buffer $\mathrm{A}$ was added to the dish to thaw the cells. The dissolved extract was aspirated, each flask was rinsed with $1 \mathrm{ml}$ of buffer $\mathrm{A}$, and the two samples were combined, all at $4^{\circ} \mathrm{C}$. The combined extracts were centrifuged for $1 \mathrm{~h}$ at $100,000 \mathrm{~g}$ in either an L8-70 using a $50 \mathrm{TI}$ rotor or a TL-100 using a TLA 100.3 rotor (Beckman Instruments Inc., Palo Alto, CA) to separate the membrane fraction (pellet) from the cytoplasmic fraction (supernatant fluid). Based on a direct comparison, this technique separated membrane-bound folate from cytoplasmic folate as well as the Percoll gradient method. The addition of unlabeled folate to the isolation buffer served to prevent cytoplasmic $\left[{ }^{3} \mathrm{H}\right]$ folate from binding to unoccupied receptors on the membrane. The unlabeled folate did not displace receptor-bound $\left[{ }^{3} \mathrm{H}\right]$ folate at $4^{\circ} \mathrm{C}$. 
Preparation of cell extracts for analysis of radiolabeled folate

Analysis of radiolabeled folate in cells was carried out as previously described (8). Likewise, cytoplasmic and membrane fractions were also analyzed using the acetic acid- $\beta$ mercaptoethanol buffer system for extracting folate from cellular extracts (8). There was one important change in the methodology. We found that iodoacetate, which was used previously as a protease inhibitor (8), interfered with the chromatographic separation of the folates. For this reason, buffer A contained leupeptin and aprotinin instead of iodoacetate to inhibit proteolysis. In the absence of iodoacetate the overall recovery of tritium that cochromatographed with an authentic folate increased from $75 \%$ as reported earlier (8) to $>90 \%$ in the current experiments.

\section{Preparation for HPLC analysis and analysis of folylpolyglutamates}

HPLC analysis of 5-methyl $\left[{ }^{3} \mathrm{H}\right]$ tetrahydrofolic acid, analogues, and metabolites was carried out exactly as described previously (8).

\section{Results}

Rate of 5-methyltetrahydrofolic acid internalization. Previously 5-methyltetrahydrofolic acid accumulation in the cytoplasm of folate-depleted MA104 cells was measured while the cells were continuously incubated in the presence of the radiolabeled folate. With this protocol we could not rule out the remote possibility that 5 -methyl $\left[{ }^{3} \mathrm{H}\right]$ tetrahydrofolic acid was entering the cell independently of the folate receptor. Therefore, to more accurately assess the delivery function of the folate receptor, MA104 cells were incubated in the presence of $40 \mathrm{nM} 5$-methyl $\left.{ }^{3} \mathrm{H}\right]$ tetrahydrofolic acid for $2 \mathrm{~h}$ at $37^{\circ} \mathrm{C}$ to allow saturation of the receptor, washed at $37^{\circ} \mathrm{C}$ to remove all extracellular ligand, and then incubated in medium alone for various times at $37^{\circ} \mathrm{C}$. At each time point cells were chilled and the quantity of acid-labile (bound to exposed receptors) and acid-resistant (internal receptors) label was measured (Fig. 1). As the chase was lengthened there was an increase in the amount of 5-methyl $\left[{ }^{3} \mathrm{H}\right]$ tetrahydrofolic acid that was resistant to acid release and a corresponding decline in the amount that was released by the acid wash. After $4 \mathrm{~h}$ at $37^{\circ} \mathrm{C}$ only $18 \%$ of the total 5 -methyl $\left[{ }^{3} \mathrm{H}\right]$ tetrahydrofolic acid remained accessible to the acid wash. Since only a small amount of the label appeared in the media (Fig. 1), the bulk of the 5 -methyl $\left[{ }^{3} \mathrm{H}\right]$ tetrahydrofolic acid initially bound at the cell surface was transported into the cell after $4 \mathrm{~h}$. The initial rate of internalization, determined by measuring the slope of the curve at the initiation of the chase, was $0.9-1.0 \mathrm{pmol} / 10^{6}$ cells per h.

The internalization of receptor-bound 5 -methyl $\left[{ }^{3} \mathrm{H}\right]-$ tetrahydrofolic acid in the absence of an exogenous source of the ligand can be divided into two steps: (a) movement of the receptor-ligand complex into an acid-resistant membrane compartment, and $(b)$ transfer across the membrane into the cytoplasm. To determine the rate of the first step we analyzed the movement of $\left[{ }^{3} \mathrm{H}\right]$ folic acid into the acid-resistant compartment since this folate remains bound to the receptor and is not delivered to the cytoplasm of the cell (8). Folate-depleted MA104 cells were incubated for $5 \mathrm{~min}$ at $37^{\circ} \mathrm{C}$ with $5 \mathrm{nM}$ $\left[{ }^{3} \mathrm{H}\right]$ folic acid, washed at $37^{\circ} \mathrm{C}$, and incubated for various times at $37^{\circ} \mathrm{C}$ before measuring acid-resistant $\left[{ }^{3} \mathrm{H}\right]$ folic acid. As shown in Fig. 2, during the first 15 min of the chase there was a linear increase in the quantity of acid-resistant $\left[{ }^{3} \mathrm{H}\right]$ folic acid associated with the cell. The decline in the apparent rate of folic acid internalization is because of receptor recycling (i.e., $\left[{ }^{3} \mathrm{H}\right]$ folic acid being initially internalized to an acid-resistant compartment and then returning again to an acid-labile state) (8). From the slope of the curve during the initial $10 \mathrm{~min}$ we calculated that the folic acid-receptor complex moved into the acid-resistant compartment at a rate of $0.9 \mathrm{pmol} / 10^{6}$ cells per $h$.

The movement of 5-methyltetrahydrofolic acid into the cytoplasm was determined by incubating the cells in the presence of 5-methyl $\left[{ }^{3} \mathrm{H}\right]$ tetrahydrofolic acid for various times at $37^{\circ} \mathrm{C}$, homogenizing the cells, and measuring the amount of label in a $100,000 \mathrm{~g}$ membrane pellet and the amount that remained in the soluble, cytoplasmic fraction (Fig. 3). After only $15 \mathrm{~min}$ of incubation there was $1.6 \mathrm{pmol} / 10^{6}$ cells of 5 -methyl $\left[{ }^{3} \mathrm{H}\right]$ tetrahydrofolic acid in the membrane fraction and virtually no label in the cytoplasmic fraction, which establishes that the 5-methyl $\left[{ }^{3} \mathrm{H}\right]$ tetrahydrofolic acid was not artifactually released from the membrane during the homogenization step. With longer incubation times, however, there was a slow rise in the amount of 5 -methyl $\left[{ }^{3} \mathrm{H}\right]$ tetrahydrofolic acid in the membrane fraction, but a rapid, linear increase in the amount in the cytoplasmic fraction. The initial rate of accumulation in the cytoplasmic fraction was calculated to be 0.8 pmol $/ 10^{6}$ cells per $\mathrm{h}$.

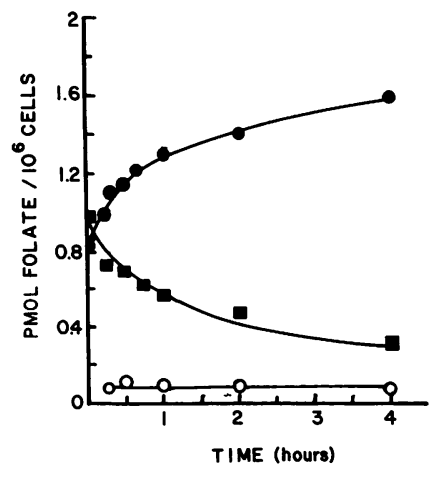
all at $37^{\circ} \mathrm{C}$. Cells were incubated for the indicated times, chilled to $4^{\circ} \mathrm{C}$, and acid-labile $(\bullet)$ and acid-resistant $(\bullet)$ radiolabeled folates measured as described. There was little loss of tritium into the medium ( 0 ).
Figure 1. Time-dependent change in the distribution of receptor-bound 5-methyl[ $\left.{ }^{3} \mathrm{H}\right]-$ tetrahydrofolic acid after incubation in folate-free medium. MA104 cells grown $4 \mathrm{~d}$ in medium A were washed with warm DPBS and incubated for $2 \mathrm{~h}$ in medium $\mathrm{B}$ containing 40 nM 5-methyl[ $\left.{ }^{3} \mathrm{H}\right]$ tetrahydrofolic acid at $37^{\circ} \mathrm{C}$. The medium was removed, the cells were washed once with warm DPBS, and fresh medium B

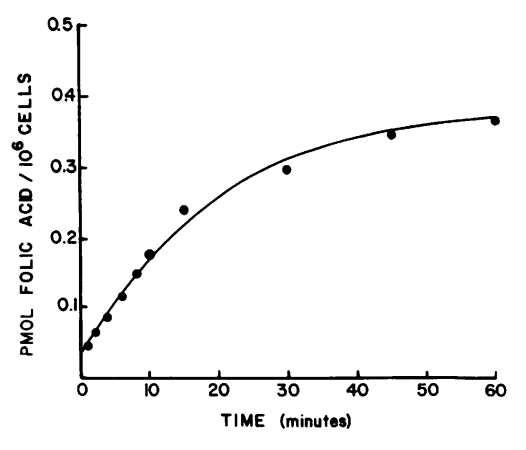

Figure 2. Change in the distribution of receptorbound $\left[{ }^{3} \mathrm{H}\right]$ folic acid at $37^{\circ} \mathrm{C}$. MA 104 cells were grown $4 \mathrm{~d}$ in medium A, washed with DPBS, and incubated 5 min in medium $B$ containing $5 \mathrm{nM}\left[{ }^{3} \mathrm{H}\right]$ folic acid at $37^{\circ} \mathrm{C}$. The medium was removed and the cells were washed once with DPBS at

$37^{\circ} \mathrm{C}$ and incubated for the indicated time with fresh medium $\mathrm{B}$ at $37^{\circ} \mathrm{C}$. At the end of each incubation the cells were chilled to $4^{\circ} \mathrm{C}$ with ice-cold DPBS. The acid-resistant $(\bullet)\left[{ }^{3} \mathrm{H}\right]$ folic acid was measured as described. 


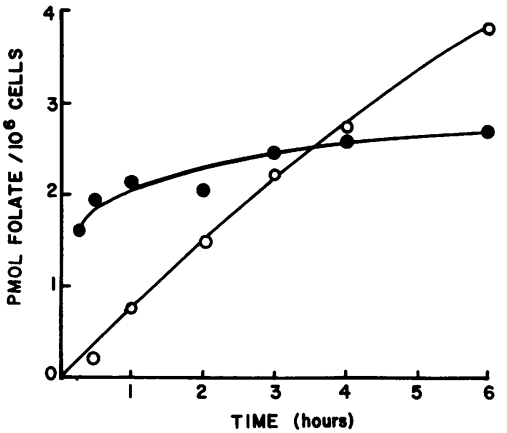
cated time. At the end of each incubation the cells were chilled to $4^{\circ} \mathrm{C}$ with ice-cold DPBS, the membrane and cytoplasmic fractions separated using the freeze-thaw/ultracentrifugation method, and the quantity of folates in each fraction measured as described.

The final step in the sequence of 5-methyltetrahydrofolate internalization is the formation of folylpolyglutamates in the cytoplasm. The kinetics of polyglutamate formation was measured by incubating folate-depleted MA104 cells in the presence of 5-methyl[ $\left.{ }^{3} \mathrm{H}\right]$ tetrahydrofolic acid for various times at $37^{\circ} \mathrm{C}$ and then measuring the amount of radiolabeled folylpolyglutamate in both the soluble cytoplasmic fraction and the membrane fraction by HPLC (8). Starting at $0.5 \mathrm{~h}$ of incubation (Fig. 4) there was a linear increase in the concentration of $\left[{ }^{3} \mathrm{H}\right]$ polyglutamate (principally 5 -methyl $\left[{ }^{3} \mathrm{H}\right]$ tetrahydrofolylpentaglutamate) in the supernatant fraction. During the same time period there was a slow but detectable appearance of $\left[{ }^{3} \mathrm{H}\right]$ polyglutamate in the membrane fraction. The rate of appearance of $\left[{ }^{3} \mathrm{H}\right]$ polyglutamate in the cytoplasmic fraction was $0.6 \mathrm{pmol} / 10^{6}$ cells per $\mathrm{h}$.

We also compared the percentage of $\left[{ }^{3} \mathrm{H}\right]$ polyglutamate vs. monoglutamate in the soluble, cytoplasmic fraction of cells incubated continuously at $37^{\circ} \mathrm{C}$ in the presence of 5 methyl $\left[{ }^{3} \mathrm{H}\right]$ tetrahydrofolic acid. Fig. 5 shows that there was a reciprocal increase in the proportion of polyglutamate and a decrease in the proportion of monoglutamate with time of incubation. Of interest was that after $7 \mathrm{~h}$ of incubation the percentage of the $\left[{ }^{3} \mathrm{H}\right]$ folate that was polyglutamated was $\sim 75-80 \%$ of the total cytoplasmic folate.

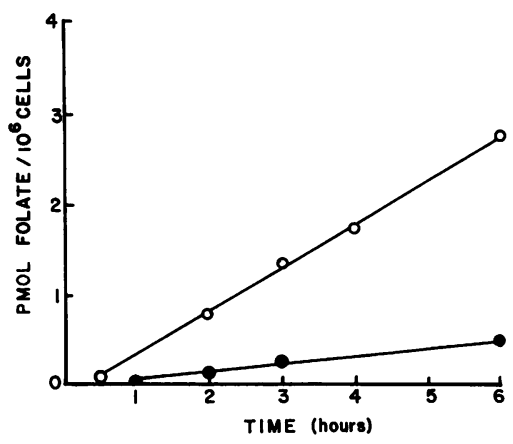

Figure 4. Accumulation of folylpolyglutamates in the cytoplasmic fraction (0) and the particulate fraction (๑) of folate-depleted MA104 cells. MA104 cells were grown for $4 \mathrm{~d}$ in me$\operatorname{dium} \mathrm{A}$. At the beginning of the experiment the medium was replaced with medium B containing $40 \mathrm{nM} 5$ -

methyl $\left[{ }^{3} \mathrm{H}\right]$ tetrahydrofolic acid and incubated at $37^{\circ} \mathrm{C}$ for the indicated time. At the end of each incubation the cells were chilled to $4^{\circ} \mathrm{C}$ with ice-cold DPBS, homogenized by freeze-thawing, and the particulate $(\bullet)$ and cytoplasmic ( $(0)$ fractions separated by ultracentrifugation. The amount of $\left[{ }^{3} \mathrm{H}\right]$ folylpolyglutamate in each fraction was measured as described.

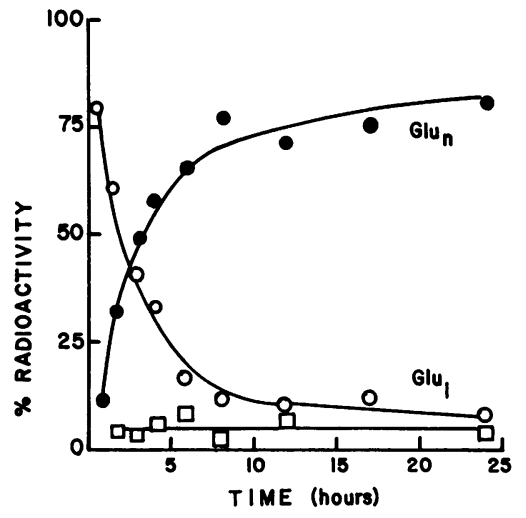

Figure 5. Change in ratio of folylpolyglutamates (๑) to folylmonoglutamate $(0)$ in the cytoplasmic fraction of folate-depleted MA104 cells. MA104 cells were grown for $4 \mathrm{~d}$ in me$\operatorname{dium}$ A. At the beginning of the experiment the medium was replaced with medium B containing $40 \mathrm{nM} 5$ methyl $\left[{ }^{3} \mathrm{H}\right]$ tetrahydrofolic acid and incubated

at $37^{\circ} \mathrm{C}$ for the indicated time. At the end of each incubation the cells were chilled and the quantity of monoglutamate (O) and polyglutamate $(\bullet)$ in the cytoplasmic fraction was determined as described (Fig. 4). The proportion of radioactivity that could not be identified () at each time was always $<10 \%$. The total folate in the cytoplasmic fraction ranged from $0.7 \mathrm{pmol} / 10^{6}$ at $1 \mathrm{~h}$ to $5 \mathrm{pmol} / 10^{6}$ cells at $24 \mathrm{~h}$ of incubation.

Folate-replete cells fail to accumulate 5-methyl[ $\left.{ }^{3} \mathrm{H}\right]$ tetrahydrofolic acid. Previous studies have shown that cellular accumulation of 5-methyltetrahydrofolate plateaus after folate-depleted cells are incubated in the presence of $40 \mathrm{nM} \mathrm{5-}$ methyl $\left[{ }^{3} \mathrm{H}\right]$ tetrahydrofolic acid for $4-6 \mathrm{~h}$ at $37^{\circ} \mathrm{C}(2,8)$. The preceding experiments suggested that the uptake of 5-methyltetrahydrofolate could be regulated at multiple sites in the internalization pathway. We first examined the effect of folate repletion on the ability of externally bound (acid-labile) 5methyl $\left[{ }^{3} \mathrm{H}\right]$ tetrahydrofolic acid to move into the acid-resistant compartment. Folate-depleted cells were incubated in the presence of $40 \mathrm{nM} 5$-methyl $\left[{ }^{3} \mathrm{H}\right]$ tetrahydrofolic acid for 2, 4, and $20 \mathrm{~h}$ at $37^{\circ} \mathrm{C}$. The cellular content of labeled folates at the end of each incubation was $3.2,3.9$, and $6.8 \mathrm{pmol} / 10^{6}$ cells, respectively. The cells were then washed with DPBS to remove extracellular ligand and incubated for an additional $0.5,1$, or 2 $h$ at $37^{\circ} \mathrm{C}$ in folate-free medium. The cells were chilled each time and the acid-labile and acid-resistant fractions were measured (Fig. 6). Cells labeled for $2 \mathrm{~h}$ before the chase (Fig. $6 \mathrm{~A}$ ) readily transferred 5 -methyl $\left[{ }^{3} \mathrm{H}\right]$ tetrahydrofolic acid from the acid-labile to the acid-resistant fractions. 4-h labeled cells (Fig. $6 \mathrm{~B}$ ) also transferred some ligand during the chase. The cells that had been incubated for $20 \mathrm{~h}$ (Fig. $6 \mathrm{C}$ ), however, did not lose any detectable 5-methyltetrahydrofolate from the acid-labile fraction, nor was there any increase in the acid-resistant fraction.

The cell fractionation technique (Fig. 3) was used to measure the effect of folate repletion on the movement of 5-methyltetrahydrofolate from the membrane fraction into the soluble, cytoplasmic fraction (Fig. 7). Folate-depleted cells were incubated in the presence of $40 \mathrm{nM} 5$-methyl[ $\left.{ }^{3} \mathrm{H}\right]$ tetrahydrofolic acid for either 2 or $12 \mathrm{~h}$. The cells were washed and then incubated in folate-free medium for the indicated time. At the end of each chase period the membrane and cytoplasmic fractions were prepared for analysis. As shown in Fig. $7 \mathrm{~A}$, cells incubated for $2 \mathrm{~h}$ transferred 5 -methyl $\left[{ }^{3} \mathrm{H}\right]$ tetrahydrofolate from the membrane to the cytoplasmic fraction. During the $1-\mathrm{h}$ chase $0.5-0.6 \mathrm{pmol} / 10^{6}$ cells left the membrane and a corresponding amount appeared in the cytoplasm. On the other hand, there was no transfer of 5-methyltetrahydrofolate 


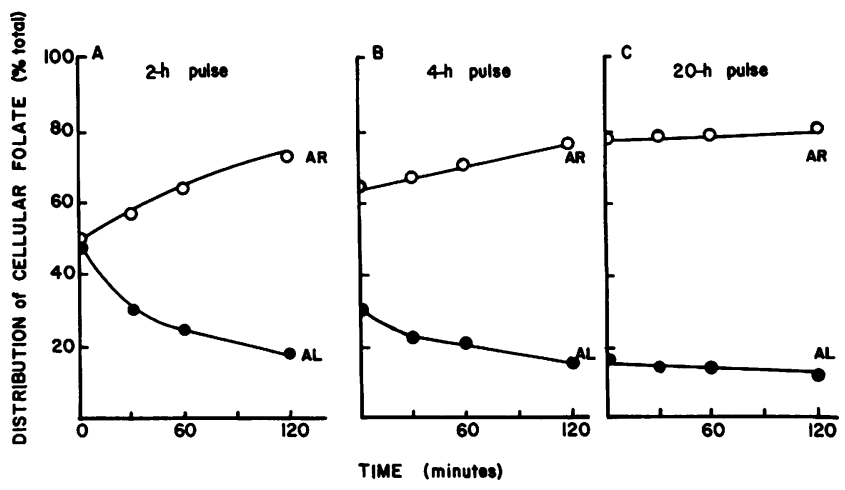

Figure 6. Effect of folate repletion on the movement of receptorbound 5-methyl $\left[{ }^{3} \mathrm{H}\right]$ tetrahydrofolic acid into the cell. MA104 cells were grown for $4 \mathrm{~d}$ in medium $\mathrm{A}$. At the beginning of the experiment the medium was replaced with medium $B$ that contained 40 nM 5-methyl $\left[{ }^{3} \mathrm{H}\right]$ tetrahydrofolic acid and the cells were incubated for $2(A), 4(B)$, or $20 \mathrm{~h}(C)$. At the end of each incubation the medium was removed, the cells were rinsed with DPBS, and fresh medium $\mathrm{B}$ was added, all at $37^{\circ} \mathrm{C}$. Each set of cells was then incubated at $37^{\circ} \mathrm{C}$ for the indicated time before chilling to $4^{\circ} \mathrm{C}$ and measuring acid-labile $(A L)$ and acid-resistant $(A R)$ 5-methyl $\left[{ }^{3} \mathrm{H}\right]$ tetrahydrofolate as described. The change in the initial ratio of $A R$ to $A L$ for each incubation time reflects the increase in 5 -methyl $\left[{ }^{3} \mathrm{H}\right]$ tetrahydrofolic acid in the AR fraction of the cell (see text). More than $90 \%$ of the radioactivity remained associated with cells during each chase time.

during the chase in cells that had been incubated with ligand for $12 \mathrm{~h}$ (Fig. $7 \mathrm{~B}$ ).

The failure of folate-replete cells to accumulate 5methyl $\left[{ }^{3} \mathrm{H}\right]$ tetrahydrofolic acid in the cytoplasmic fraction could be due to either an inhibition of transfer from the recep-

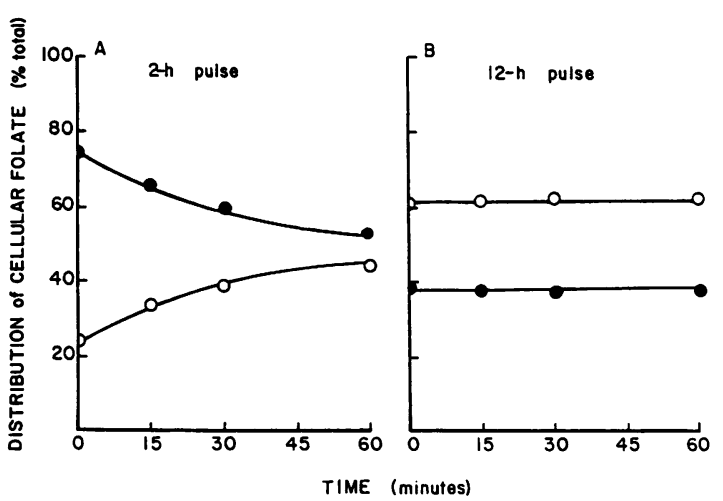

Figure 7. Effect of folate repletion on the movement of 5-methyl $\left[{ }^{3} \mathrm{H}\right]-$ tetrahydrofolic acid from the membrane fraction (๑) to the cytoplasmic fraction (O). MA 104 cells were grown for $4 \mathrm{~d}$ in medium A. At the beginning of the experiment the medium was replaced with medium B containing $40 \mathrm{nM} 5-$ methyl[ $\left.{ }^{3} \mathrm{H}\right]$ tetrahydrofolic acid and the cells were incubated for either $2(A)$ or $12 \mathrm{~h}(B)$. At the end of the incubation the medium was removed, the cells were washed with DPBS, and fresh medium B was added, all at $37^{\circ} \mathrm{C}$. Each set of cells was then incubated at $37^{\circ} \mathrm{C}$ for the indicated time before subjecting them to the homogenization and fractionation procedure as described. The quantity of radiolabeled 5-methyltetrahydrofolate in the membrane fraction ( $\bullet$ ) and the cytoplasmic fraction ( 0 ) was measured as described. The quantity of 5 -methyl $\left[{ }^{3} \mathrm{H}\right]$ tetrahydrofolic acid that was transferred from the membrane fraction to the cytoplasmic fraction during the $1-\mathrm{h}$ chase was $0.5-0.6 \mathrm{pmol} / 10^{6}$ cells $(A)$ and 0 pmol $/ 10^{6}$ cells $(B)$. tor to the cytoplasm or an inhibition of receptor movement between the acid-labile and acid-resistant membrane fractions. As shown previously (8), receptor movement can be detected by first labeling both internal and external receptors with 5methyl $\left[{ }^{3} \mathrm{H}\right]$ tetrahydrofolate, removing 5 -methyl $\left[{ }^{3} \mathrm{H}\right]$ tetrahydrofolate from externally oriented receptors by acid treatment, allowing the cells time to return internal, occupied receptors to an external location, and assaying for the quantity of radiolabeled 5-methyltetrahydrofolate bound to these externalized receptors. If the two receptor populations completely mix, $50 \%$ of the occupied, acid-resistant fraction should become acid labile (8). Cells were incubated in the presence of $40 \mathrm{nM} 5-$ methyl $\left[{ }^{3} \mathrm{H}\right]$ tetrahydrofolic acid for $22 \mathrm{~h}$ and subjected to an acid wash treatment at $37^{\circ} \mathrm{C}$. 1 pmol/10 $10^{6}$ cells of 5-methyltetrahydrofolate was released (Fig. 8). The same set of cells was then incubated at $37^{\circ} \mathrm{C}$ for $30 \mathrm{~min}$ to allow occupied receptors in the acid-resistant fraction (containing $1 \mathrm{pmol} / 10^{6}$ cells of radiolabeled 5-methyltetrahydrofolate) to move to the acid-labile fraction. When these cells were acid washed, 0.55 pmol $/ 10^{6}$ cells of 5 -methyl $\left[{ }^{3} \mathrm{H}\right]$ tetrahydrofolic acid was released. The cells were repeatedly acid washed and incubated at $37^{\circ} \mathrm{C}$; each time approximately one-half of the remaining membrane capacity was released. By contrast, this repeated acid wash procedure only lowered the cytoplasmic fraction by $10-15 \%$ (data not shown).

The combined acid-labile and acid-resistant receptor pools bind $\sim 2 \mathrm{pmol} / 10^{6}$ cells of 5-methyltetrahydrofolic acid (8). If the two groups exchange with each other, continuous incubation of cells in the presence of an agent that displaces receptor-bound 5-methyl $\left[{ }^{3} \mathrm{H}\right]$ tetrahydrofolic acid from the receptor should release 2 pmol $/ 10^{6}$ cells of 5 -methyltetrahydrofolate, but only half this amount if they do not exchange. Therefore, as another test of receptor movement in folate-replete cells, cells were incubated in the presence of 5 -methyl $\left[{ }^{3} \mathrm{H}\right]-$ tetrahydrofolic acid for $22 \mathrm{~h}$, washed, and then either incubated for $8 \mathrm{~h}$ in the presence of $10 \mu \mathrm{M}$ methotrexate to displace bound 5-methyltetrahydrofolate, or subjected to the multiple acid wash protocol. As shown in Table I, both methotrexate displacement and multiple acid washes released $\sim 2.0$ pmol $/ 10^{6}$ cells of 5 -methyl $\left[{ }^{3} \mathrm{H}\right]$ tetrahydrofolic acid. Neither treatment caused a significant change in the amount of 5methyltetrahydrofolate in the cytoplasm because nearly all of the cell-associated label (Table I) was found in the supernatant

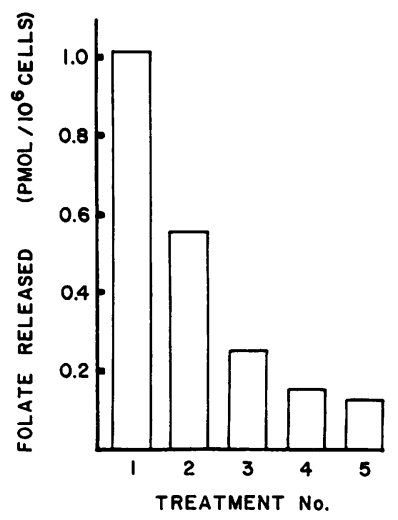

Figure 8. Movement of 5methyl $\left[{ }^{3} \mathrm{H}\right]$ tetrahydrofolic acid from the acid-resistant to the acidlabile receptor fraction in folatereplete cells. MA104 cells were grown for $4 \mathrm{~d}$ in medium $A$. At the beginning of the experiment the medium was replaced with medium B containing $40 \mathrm{nM} 5$ methyl $\left[{ }^{3} \mathrm{H}\right]$ tetrahydrofolic acid and incubated for $22 \mathrm{~h}$ at $37^{\circ} \mathrm{C}$. The same set of cells was then subjected to repeated acid washes $\left(30 \mathrm{~s}\right.$ at $\left.37^{\circ} \mathrm{C}\right)$, followed in each case by a 30 -min incubation in medium B at $37^{\circ} \mathrm{C}$. The cycle was repeated five times (treatment No.) and the quantity of radiolabeled 5-methyltetrahydrofolate released with each acid wash was measured. 
Table I. Effects of Acid Wash and Methotrexate on Release of Folates

\begin{tabular}{lcc}
\hline & \multicolumn{2}{c}{ Folates } \\
\cline { 2 - 3 } Treatment & Released & Cell associated \\
\hline & \multicolumn{2}{c}{$p$ pmol/10 cells } \\
Acid wash & 2.2 & 4.7 \\
Methotrexate & 2.1 & 5.2 \\
\hline
\end{tabular}

MA104 cells were grown for $5 \mathrm{~d}$ in medium A. At the beginning of the experiment the medium was replaced with medium $B$ containing $24 \mathrm{nM} 5$-methyl[ $\left.{ }^{3} \mathrm{H}\right]$ tetrahydrofolic acid and incubated for $22 \mathrm{~h}$ at $37^{\circ} \mathrm{C}$. At the end of the incubation one set of cells was washed with DPBS at $37^{\circ} \mathrm{C}$ and processed to release radiolabeled 5-methyltetrahydrofolate by the repeated $37^{\circ} \mathrm{C}$ acid wash procedure at $0,2,4$, and $8 \mathrm{~h}$ of incubation at $37^{\circ} \mathrm{C}$ in medium $\mathrm{B}$. All acid washes were at $37^{\circ} \mathrm{C}$. A second set of cells was washed with $37^{\circ} \mathrm{C}$ DPBS and incubated for $8 \mathrm{~h}$ in fresh medium B containing $10 \mu \mathrm{M}$ methotrexate at $37^{\circ} \mathrm{C}$. At the end of 2 and $4 \mathrm{~h}$ in methotrexate the medium was removed and fresh medium B containing $10 \mu \mathrm{M}$ methotrexate was added to the dish. The medium at each time point was analyzed for the amount of $\left[{ }^{3} \mathrm{H}\right]$ folates released. These values were combined to give total $\left[{ }^{3} \mathrm{H}\right]$ folates released. More than $85 \%$ of the total $\left[{ }^{3} \mathrm{H}\right]$ folates that were released occurred during the first $2 \mathrm{~h}$ of incubation in 10 $\mu \mathrm{M}$ methotrexate.

fraction when we used the freeze-thaw assay to separate membranes from cytoplasm (data not shown).

The acid-labile 5-methyl $\left[{ }^{3} \mathrm{H}\right]$ tetrahydrofolic acid that appeared at the cell surface during the $37^{\circ} \mathrm{C}$ incubation after each acid wash (Fig. 8) must have come from the acid-resistant receptor pool. This experiment did not rule out the possibility, however, that with time the empty receptors generated during the acid wash can acquire 5-methyltetrahydrofolate from the cytoplasm. Fig. 9 shows that even when cells were incubated up to $4 \mathrm{~h}$ after an acid wash that removed 5 -methyl $\left[{ }^{3} \mathrm{H}\right]$ tetrahydrofolic acid from receptors exposed at the cell surface, the receptors remained empty. That is, there was no increase in the amount of labeled 5-methyltetrahydrofolate released in the second acid wash.

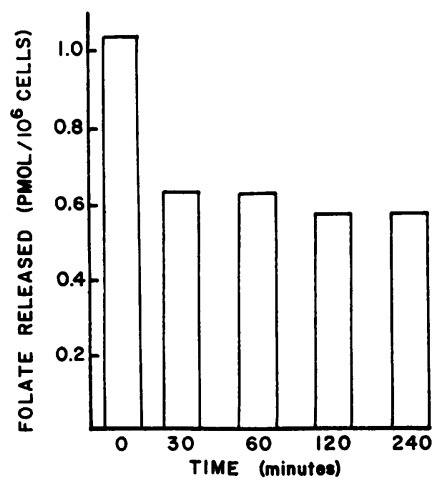

Figure 9. The effect of incubation time on the transfer of 5methyl $\left[{ }^{3} \mathrm{H}\right]$ tetrahydrofolic acid from the acid-resistant receptor fraction to the acid-labile receptor fraction in folate-replete cells. MA104 cells were grown for $4 \mathrm{~d}$ in medium $A$. At the beginning of the experiment the medium was replaced with medium $B$ containing 40 nM 5-methyl[ $\left.{ }^{3} \mathrm{H}\right]-$ tetrahydrofolic acid and incubated for $22 \mathrm{~h}$ at $37^{\circ} \mathrm{C}$.

The cells were washed with DPBS at $37^{\circ} \mathrm{C}$, treated with acid saline at $37^{\circ} \mathrm{C}$, and then incubated at $37^{\circ} \mathrm{C}$ in medium $\mathrm{B}$ for an additional 0 , $30,60,120$, and $240 \mathrm{~min}$ before chilling to $4^{\circ} \mathrm{C}$ and doing a second acid wash. The amount of radiolabeled 5-methyltetrahydrofolate in the acid wash was measured as described.

\section{Discussion}

To establish a function for the folate receptor in delivering 5-methyltetrahydrofolic acid to the cytoplasm of folate-depleted cells, each step in the movement of receptor-bound 5-methyltetrahydrofolate from the cell surface into the cytoplasm must be identified. Our previous studies suggested that a key event in initiating this traffic pattern was the cyclic movement of the receptor from the cell surface into a membranebound vacuole and back to the cell surface (8). The current results indicate that when the cells are incubated with 5methyl $\left[{ }^{3} \mathrm{H}\right]$ tetrahydrofolic acid at $37^{\circ} \mathrm{C}$, washed, and incubated for various times without changing the temperature, the surface-bound 5-methyltetrahydrofolate moves into the cell. This establishes that the receptor can directly deliver 5-methyltetrahydrofolate to the cell interior. Approximately $1 \mathrm{pmol}$ of folates per $10^{6}$ cells will bind to externally oriented receptors, which corresponds to $\sim 600,000$ receptors exposed at the surface of each cell. Based on the initial rate of disappearance from the acid-labile sites $\left(0.9 \mathrm{pmol} / 10^{6}\right.$ cells per $\left.\mathrm{h}\right)$, each minute $1.5 \%$ of the receptors (or 9,000 molecules) are internalized.

Kinetics of transport. Since the final destination of the 5methyltetrahydrofolic acid is the cytoplasm, we were interested in comparing the rate of receptor internalization (transfer of acid-labile to an acid-resistant compartment) with the rate of ligand delivery to the cytoplasm. We measured the former by following the movement of $\left[{ }^{3} \mathrm{H}\right]$ folic acid, since this folate remains bound to the receptor as it recycles instead of accumulating in the cytoplasm (8). On the other hand, the rate of movement of 5-methyl $\left.{ }^{3} \mathrm{H}\right]$ tetrahydrofolic acid into the cytoplasm was measured by using centrifugation to separate the membrane fraction from the cytoplasmic fraction at various times after the cells were incubated in the presence of the ligand at $37^{\circ} \mathrm{C}$. This strategy revealed that the initial rate of receptor internalization and the initial rate of delivery to the cytoplasm were nearly identical $\left(0.8-0.9 \mathrm{pmol} / 10^{6}\right.$ cells per $\left.\mathrm{h}\right)$. Since the rate of disappearance of 5-methyl $\left[{ }^{3} \mathrm{H}\right]$ tetrahydrofolic acid bound to externally oriented receptors (Fig. 1) was 0.9 pmol $/ 10^{6}$ cells per $\mathrm{h}$, in the time frame of this experiment $(4 \mathrm{~h})$ most of the ligand must have appeared in the cytoplasm (see Fig. $7 \mathrm{~A}$ ). These kinetic measurements implicate the receptor internalization step as being necessary for delivery of 5-methyltetrahydrofolic acid to the cytoplasm.

The conversion of 5-methyl[ $\left.{ }^{3} \mathrm{H}\right]$ tetrahydrofolic acid from a monoglutamate to a polyglutamate may be important for retention of the folate in the cell as well as other physiologic functions (reviewed in reference 23). The folate-depleted cell offers a unique opportunity to measure both the rate of conversion of monoglutamate to polyglutamate as well as the proportion of cytoplasmic folate that is polyglutamated during 5-methyltetrahydrofolate accumulation. Almost as soon as 5methyl $\left[{ }^{3} \mathrm{H}\right]$ tetrahydrofolic acid reached the cytoplasm, polyglutamate derivatives were formed. Moreover, the rate of polyglutamate formation was only slightly slower than the rate of 5-methyltetrahydrofolate delivery to the cytoplasm, which indicates that the delivery system can supply enough substrate for the polyglutamate synthetase enzyme. After $6 \mathrm{~h}$ the fraction of 5-methyltetrahydrofolic acid that was polyglutamated was $75-80 \%$, which is the proportion of total 5-methyltetrahydrofolate ordinarily found as a polyglutamate in cultured MA104 cells grown in physiologic concentrations of folate. 
Regulation of transport. A characteristic behavior of the folate-depleted tissue culture cell is that after 4-6 $\mathrm{h}$ of incubation in the presence of 5-methyl[ $\left[{ }^{3} \mathrm{H}\right]$ tetrahydrofolic acid, 5methyltetrahydrofolate accumulation begins to level off $(2,8)$. At this time the amount accumulated corresponds to the concentration found in MA104 cells cultured in regular medium (5-7 pmol/10 cells). Eventually the number of folate receptors declines when cells are grown in the presence of adequate amounts of the vitamin (24); however, this loss is too slow to account for the acute regulation of uptake.

We searched for several potential causes of this acute regulation in 5-methyltetrahydrofolate uptake: $(a)$ receptor inactivation; $(b)$ inhibition of receptor recycling; $(c)$ competition for receptor binding by intracellular folate; and $(d)$ inhibition of transmembrane transport. Using two different assays we found a marked inhibition of 5-methyl $\left[{ }^{3} \mathrm{H}\right]$ tetrahydrofolic acid movement from the cell surface receptor into the cytoplasm when cells had physiological levels of intracellular folates. The receptors in folate-replete cells bound normal levels of 5methyl $\left[{ }^{3} \mathrm{H}\right]$ tetrahydrofolic acid. They also recycled properly, as indicated by the methotrexate replacement assay (Table I) and the multiple acid wash assay (Fig. 8). Neither treatment would have completely displaced both acid-resistant and acidlabile, membrane-bound 5-methyltetrahydrofolate (2 $\mathrm{pmol} / 10^{6}$ cells) unless the receptors were recycling. The rate of cycling also was unchanged as compared with folate-depleted cells (compare Fig. 8 with Fig. 6 in reference 8). To see if cytoplasmic folates were competing with extracellular 5-methyltetrahydrofolate for binding to receptors in replete cells (Fig. 9) we generated empty receptors at the cell surface by acid washing, allowed the unoccupied receptors to cycle for various times at $37^{\circ} \mathrm{C}$, and then assayed for the number of occupied receptors by doing a second acid wash. These experiments showed that the acid-stripped receptors remained empty. Therefore, the receptor appears not to be accessible to cytoplasmic folates. This leaves transmembrane transport as the likely site of regulation.

Exactly how regulation of movement across the membrane is achieved remains to be elucidated. Much more needs to be known about how the charged 5-methyltetrahydrofolate molecule traverses the membrane. A considerable body of research implicates a folate transporter or carrier molecule as mediating uptake by cells. Conceivably the folate receptor is coupled to such a transporter molecule.

Receptor coupled transmembrane transport. The function of the folate receptor may be to concentrate the 5-methyltetrahydrofolic acid to a level that allows for optimal transport by a folate transporter. There are many examples where membrane receptors function to concentrate specific molecules at the cell surface. In eukaryotic cells the best example is receptor-mediated endocytosis, which is crucial for delivery of metabolically important molecules to the interior of cells (25). A transport mechanism that appears to be more analogous to folate transport, however, is the periplasmic transport system in gram-negative bacteria (26). There is considerable evidence that low molecular weight nutrients such as histidine (27), maltose (28), $\beta$-methyl galactoside $(29,30)$, phosphate $(31)$, and cobalamin (32) are delivered to the cytoplasm of these bacteria by a periplasmic permease complex that consists of a high affinity substrate-binding protein and one to three membrane-bound components. The substrate-binding protein con- centrates the nutrient in the periplasm and transfers it to the membrane-bound component, which moves it across the inner membrane. This mechanism has evolved in bacteria because of the need to concentrate molecules in the cell against gradients as large as $10^{5}$-fold (26).

Summary. In the cultured MA104 cell the folate receptor allows the cell to accumulate micromolar amounts of folate when the 5-methyltetrahydrofolate present in the medium is at concentrations of only $20-40 \mathrm{nM}$. Although this receptor is present in other cultured cell lines and apparently induced by growth in physiological rather than pharmacological folate (33-35), there is no information about how the receptor functions in vivo. This is an important future goal.

The folate transport system uncovered by studying folatedepleted tissue culture cells $(1,2,8,24,33-35)$ may be an example of a concentrative mechanism used by eukaryotic cells to take up a wide variety of important low molecular weight molecules. We hope that further work on the folate receptor will lead to a better understanding of how this transport system delivers molecules to the cell interior.

\section{Acknowledgments}

This work was supported by American Cancer Society grant $\mathrm{CH}-228$ to Dr. Kamen, who is also a Burroughs Wellcome Scholar in Clinical Pharmacology.

\section{References}

1. Antony, A. C., M. A. Kane, R. M. Portillo, P. C. Elwood, and J. F. Kolhouse. 1985. Studies of the role of a particulate folate-binding protein in the uptake of 5-methyltetrahydrofolate by cultured human KB cells. J. Biol. Chem. 260:14911-14917.

2. Kamen, B. A., and A. Capdevila. 1986. Receptor mediated folate and methotrexate transport is regulated by the intracellular folate pool. Proc. Natl. Acad. Sci. USA. 83:5983-5987.

3. Kane, M. A., P. C. Elwood, R. M. Portillo, A. C. Antony, and J. F. Kolhouse. 1986. The interrelationship of the soluble and membrane associated folate-binding proteins in human KB cells. J. Biol. Chem. 261:15625-15631.

4. Kamen, B. A., and J. D. Caston. 1975. Purification of folate binding factor in normal umbilical cord serum. Proc. Natl. Acad. Sci. USA. 72:4261-4264.

5. Mantzos, J. D., V. Alevizou-Terzaki, and E. Gyftaki. 1974. Folate binding in animal plasma. Acta Haematol. (Basel). 51:204-210.

6. Salter, D. N., J. E. Ford, K. J. Scott, and B. Andrews. 1972. Isolation of the folate-binding protein from cow's milk by the use of affinity chromatography. FEBS (Fed. Eur. Biochem. Soc.) Lett. 20:302-306.

7. Antony, A. C., C. Utley, K. C. Van Horne, and J. F. Kolhouse. 1981. Isolation and characterization of a folate receptor from human placenta. J. Biol. Chem. 256:9684-9692.

8. Kamen, B. A., M.-T. Wang, A. J. Streckfuss, X. Peryea, and R. G. W. Anderson. 1988. Internalization of folates is mediated by a surface membrane receptor that recycles. J. Biol. Chem. 263:1360213609.

9. Lacey, S. W., J. M. Sanders, K. G. Rothberg, R. G. W. Anderson, and B. A. Kamen. 1989. Complementary DNA for the folate binding protein correctly predicts anchoring to the membrane by glycosylphosphatidylinositol. J. Clin. Invest. 84:715-720.

10. Sadasivan, E., and S. P. Rothenberg. 1988. Molecular cloning of the complementary DNA for a human folate binding protein. Proc. Soc. Exp. Biol. Med. 189:240-244.

11. Sadasivan, E., and S. P. Rothenberg. 1989. The complete amino acid sequence of a human folate binding protein from KB cells determined from the cDNA. J. Biol. Chem. 264:5806-5811. 
12. Svendsen, I., S. I. Hansen, J. Holm, and J. Lyngbye. 1984. The complete amino acid sequence of the folate-binding protein from cow's milk. Carlsberg Res. Commun. 49:123-131.

13. Low, M. G. 1987. Biochemistry of the glycosyl-phosphatidylinositol membrane protein anchors. Biochem. J. 244:1-13.

14. Elwood, P. C., M. A. Kane, R. M. Portillo, and J. F. Kolhouse. 1986. The isolation, characterization, and comparison of the membrane-associated and soluble folate-binding protein from human $\mathrm{KB}$ cells. J. Biol. Chem. 261:15416-15423.

15. Luhrs, C. A., P. Pitiranggon, M. daCosta, S. P. Rothenberg, B. L. Slomiany, L. Brink, G. I. Tous, and S. Stein. 1987. Purified membrane and soluble folate binding proteins from cultured $\mathrm{KB}$ cells have similar amino acid compositions and molecular weights but differ in fatty acylation. Proc. Natl. Acad. Sci. USA. 84:6546-6549.

16. Henderson, G. B., M. R. Suresh, K. S. Vitols, and F. M. Huennekens. 1986. Transport of folate compounds in L1210 cells: kinetic evidence that folate influx proceeds via the high-affinity transport system for 5-methyltetrahydrofolate and methotrexate. Cancer Res. 46:1639-1643.

17. Henderson, G. B., B. Grzelakowska-Sztabert, E. M. Zevely, and F. M. Huennekens. 1980. Binding properties of the 5-methyltetrahydrofolate/methotrexate transport system in L1210 cells. Arch. Biochem. Biophys. 202:144-149.

18. Yang, C.-H., F. M. Sirotnak, and L. S. Mines. 1988. Further studies on a novel class of genetic variants of the L1210 cell with increased folate analogue transport inward. J. Biol. Chem. 263:97039709.

19. Sirotnak, F. M. 1985. Obligate genetic expression in tumor cells of a fetal membrane property mediating "folate" transport: biological significance and implications for improved therapy of human cancer. Cancer Res. 45:3992-4000.

20. Henderson, G. B., and E. M. Zevely. 1984. Affinity labeling of the 5-methyltetrahydrofolate/methotrexate transport protein of L1210 cells by treatment with an $\mathrm{N}$-hydroxysuccinimide ester of [3H]methotrexate. J. Biol. Chem. 259:4558-4562.

21. Price, E. M., and J. H. Freisheim. 1987. Photoaffinity analogues of methotrexate as folate antagonist binding probes. 2 . Transport studies, photoaffinity labeling, and identification of the membrane carrier protein for methotrexate from murine L1210 cells. Biochemistry. 26:4757-4763.

22. Bradford, M. M. 1976. A rapid and sensitive method for the quantitation of microgram quantities of protein utilizing the principle of protein-dye binding. Anal. Biochem. 72:248-254.

23. Kamen, B. A. 1987. Folic acid antagonists. In Metabolism and
Action of Anti-Cancer Drugs. G. Powis, and R. A. Prough, editors. Taylor \& Francis, New York. 141-162.

24. Kane, M. A., P. C. Elwood, R. M. Portillo, A. C. Antony, V. Najfeld, A. Finley, S. Waxman, and J. F. Kolhouse. 1988. Influence on immunoreactive folate-binding proteins of extracellular folate concentration in cultured human cells. J. Clin. Invest. 81:1398-1406.

25. Anderson, R. G. W., and J. Kaplan. 1983. Receptor-mediated endocytosis. In Modern Cell Biology. B. Satir, editor. Alan R. Liss, Inc., New York. 1:1-52.

26. Ames, G. F.-L. 1986. Bacterial periplasmic transport systems: structure, mechanism, and evolution. Annu. Rev. Biochem. 55:397425.

27. Higgins, C. F., P. D. Haag, K. Nikaido, F. Ardeshir, G. Garcia, and G. L. Ames. 1982. Complete nucleotide sequence and identification of membrane components of the histidine transport operon of $\mathrm{S}$. typhimurium. Nature (Lond.). 298:723-727.

28. Hengge, R., and W. Boos. 1983. Maltose and lactose transport in Escherichia coli: examples of two different types of concentrative transport systems. Biochim. Biophys. Acta. 737:443-478.

29. Harayama, S., J. Bollinger, T. Iino, and G. L. Hazelbauer. 1983. Characterization of the mgl operon of Escherichia coli by transposon mutagenesis and molecular cloning. J. Bacteriol. 153:408-415.

30. Robbins, A. R., R. Guzman, and B. Rotman. 1976. Roles of individual $\mathrm{mgl}$ gene products in the beta-methylgalactoside transport system of Escherichia coli K12. J. Biol. Chem. 251:3112-3116.

31. Amemura, M., K. Makino, H. Shinagawa, A. Kobayashi, and A. Nakata. 1985. Nucleotide sequence of the genes involved in phosphate transport and regulation of the phosphate regulon in Escherichia coli. J. Mol. Biol. 184:241-250.

32. Sennett, C., L. E. Rosenberg, and I. S. Mellman. 1981. Transmembrane transport of cobalamin in prokaryotic and eucaryotic cells. Annu. Rev. Biochem. 50:1053-1086.

33. Henderson, G. B., J. M. Tsuji, and H. P. Kumar. 1988. Mediated uptake of folate by a high-affinity binding protein in sublines of L1210 cells adapted to nanomolar concentrations of folate. J. Membr. Biol. 101:247-258.

34. Jansen, G., I. Kathmann, B. C. Rademaker, B. J. M. Braakhuis, G. R. Westerhhof, G. Rijksen, and J. H. Schornagel. 1989. Expression of a folate binding protein in L1210 cells grown in low folate medium. Cancer Res. 49:1959-1963.

35. Jansen, G., G. R. Westerhof, I. Kathmann, B. C. Rademaker, G. Rijksen, and J. H. Schornagel. 1989. Identification of membraneassociated folate-binding protein in human leukemic CCRF-CEM cells with transport-related methotrexate resistance. Cancer Res. 49:2455-2459. 